\title{
Facilitation as a teaching strategy : experiences of facilitators
}

\author{
E Lekalakala-Mokgele \\ School of Nursing, University of the Free State
}

\section{Keywords:}

Teaching strategies, facilities, facilitators experience

\section{Correspondence address:}

E Lekalakala-Mokgele

School of Nursing

University of the Free State

PO Box 339

Bloemfontein, 9300

Tel : (051) 401-2407

Fax : (051) 9463

E-mail : gnvkem.md@mail.uovs.ac.za

\section{Abstract: Curationis 29(3): 61-69}

Changes in nursing education involve the move from traditional teaching approaches that are teacher-centred to facilitation, a student centred approach. The studentcentred approach is based on a philosophy of teaching and learning that puts the learner on centre-stage. The aim of this study was to identify the challenges of facilitators of learning using facilitation as a teaching method and recommend strategies for their (facilitators) development and support. A qualitative, explorative and contextual design was used. Four (4) universities in South Africa which utilize facilitation as a teaching/ learning process were identified and the facilitators were selected to be the sample of the study. The main question posed during in-depth group interviews was: How do you experience facilitation as a teaching/learning method?. Facilitators indicated different experiences and emotions when they first had to facilitate learning. All of them indicated that it was difficult to facilitate at the beginning as they were trained to lecture and that no format for facilitation was available. They experienced frustrations and anxieties as a resuit. The lack of knowledge of facilitation instilled fear in them. However they indicated that facilitation had many benefits for them and for the students. Amongst the ones mentioned were personal and professional growth. Challenges mentioned were the fear that they waste time and that they do not cover the content. It is therefore important that facilitation be included in the training of nurse educators.

\section{Opsomming}

Verandering in verpleegonderrig behels klemverskuiwing vanaf tradisionele onderrigbenaderings wat dosent-gesentreerd is na 'n meer student- gesentreerde benadering. Die student-gesentreerde benadering is op die filosofie van onderrig en leer wat die leerder as die sentrale fokuspunt stel, gebaseer. Die doelstelling van die studie was om die uitdagings wat fasiliteerders in verpleegonderrig in die oë staar, vas te stel wanneer hulle fasilitering as onderrig metode sou gebruik asook om strategieë vir die ontwikkeling en ondersteuning van fasiliteerders daar te stel. "? Kwalitatiewe ontwerp van? verkennende en kontekstuele aard is gebruik. Vier (4) universiteite in Suid Afrika wat fasilitering as onderrig-metodiek gebruik, is geïdentifiseer en al die fasiliteerders is in die steekproef opgeneem. Die enigste vraag wat tydens die indiepte onderhoud gestel is, het soos volg gelei: "Hoe ervaar u fasilitering as "? onderrig/ leer metode in verpleegonderrig?" Volgens die fasiliteerders het hulle in die begin stadium van leer fasilitering uiteenlopende ervarings en emosies ondervind. Verder het hulle ook aangedui dat dit moeilik in die begin was om te fasiliteer, omrede hulle opgelei is om te onderrig en omdat daar geen handleiding rakende fasilitering beskikbaar is nie. Die fasiliteerders het op grond hiervan frustrasie en angs beleef. Hul gebrek aan kennis oor fasilitering het hul angstigheid vererger. Ten spyte hiervan, was hulle egter van mening dat fasilitering voordele vir beide die student en die fasiliteerder inhou. Van die voordele wat gemeld is, is persoonlike en professionele groei. Uitdagings wat in die oë gestaar moes word, was die vrees dat hulle besig was om tyd te mors asook dat hulle nie die inhoudelik voldoende sou dek nie. Gegrond hierop blyk dit dus dat fasiliteringsriglyne in die opleiding van verpleegopvoeders ingesluit behoort te word. 


\section{Introduction}

Higher education in general is presently under both internal and external pressure to change and this transformation has put nursing education in the spotlight to change. Evidence of this change is the transfer of hospital-based to communitybased education and the introduction of non-traditional methods such as problem-based learning (PBL), community-based education (CBE) as well as inquiry-based learning (IBL). These methods emphasize that effective learning cannot be limited to the delivery of information but that the active participation of the learner is essential (Dolmas, Gijselaers, De Grave, Wolfhagen \& Van der Vleuten, 2002: 173). The transformation served as major stimulus for change in the education of health professionals including nurses ( Mtshali, 2005:5).

Changes in nursing education have a direct influence on nurse educators as they have to keep abreast of the changes occurring in their profession. Their role as teachers, governed by behaviourist ideology which is still dominant in educational programs in South Africa, are put under the spotlight to change to a student-centred approach. Central to this challenge is the desire to achieve meaningful, lifelong learning and personal growth. The focus on transformation in nursing education is the development of a student nurse to be a critical thinker and a self-directed learner.

The starting point would be the revision of the traditional teaching role of the lecturer of imparting knowledge to facilitating the learning (Dolmas et al, 2002: 173). Effective learning is possible when the role of the teacher is not that of a controller and deliverer of pre-packed knowledge and the dictator of what the student should learn to facilitation which demands a shift from teacher to studentcentred instruction (Kwan, 2004:1186, Johnston \& Tinning, 2001:161). Changing the teaching role to facilitation necessitates that guidelines for facilitation should be developed because in the past lecturers were trained to lecture and not to facilitate learning.

\section{Research problem}

Problem-based learning methodologies are now extensively utilized within contemporary nursing curriculum (Johnston \& Tinning, 2001:161, Haith-
Cooper, 2003:65). The School of Nursing of the Free State University introduced problem-based learning (PBL) in 1997. With the introduction of PBL, the planning of the curriculum was extensive, the focus was on the process of PBL and not much on facilitation. All lectures were trained to lecture and not to facilitate learning. Lecturers aired their concerns: they felt insecure in facilitating learning. Their main concern was that they had not received adequate preparation for their new role and that they found it difficult to adapt to this mode of teaching.

Most lecturers at that time had primarily lecturer-based experience and had no role models they could emulate to facilitate learning. Moving out of the traditional didactic style of teaching to facilitation of learning was difficult for many. Most facilitation was learned by trial and error and there was no role model or expert who could demonstrate good facilitation. This was confirmed by research conducted by Fichardt \& du Rand (2000: 3) on assessing the perceptions of facilitators of PBL and CBE in the school of Nursing of the Free State University. Based on these statements there was a need to address the challenges that facilitators were facing regarding their new role of facilitation and recommend measures to assist them to adapt to this mode of teaching

\section{Aim of the study}

The aim of this study was to identify the challenges of facilitators of learning using facilitation as a teaching method and recommend strategies for their development and support.

Objectives of the study are to:

-
facilitators
identify problems of facilitators
recommend the strategies for
developing and supporting
facilitators to assist them in
adapting to the process of
facilitation.

\section{Research design}

A qualitative explorative descriptive and contextual approach was used to identify the challenges of facilitation faced by facilitators of learning in a problem-based setting. One main question posed during in-depth group interviews was: How do you experience facilitation as a teaching/ learning method?.

\section{Population and sampling}

The population of this study was purposively selected which is common in qualitative research ( Polit, Beck \& Hunlger, 2001:246). The sample of this study included the facilitators in the schools and departments of nursing of four (4) South African universities using facilitation as a teaching-learning method.

\section{Data collection and analysis}

Data was collected by conducting focus group interviews. In total four (4) focus group interviews were conducted with facilitators, one in each university with members ranging between 6-10 members whose opinions and experiences of facilitation were solicited simultaneously (Polit, et al, 2001:268). Each group consisted of facilitators of first up to the fourth year of study. The purpose of the interviews for this study was to obtain in-depth information from a few cases. This is characteristic of qualitative research (Moloto, 1999:38). Data was collected until saturation was reached. Chakalane-Mpeli (2004: 27) and Streubert Speziale and Carpenter, (2003:33) state that saturation of data is the determinant of sample size which occurs when there is emergence of repeating themes. Interviews were conducted by the moderator. According to Moloto (1999:57) the researcher and moderator in focus groups are one and the same. In this research the researcher and the moderator were two different people and had different roles. The researcher was an observer taking field notes whereas the moderator was the facilitator of focus group interviews, controlling the dynamics within the groups, such as dominating individuals and help prevent group conformity (Babbie, 2004:305). The moderator was a psychiatric nurse specialist skilled and experienced in focus group management. She is also an expert in qualitative research and was familiar with the research. Field notes were taken to record observations, capture actual discussions, communications and perceptions since memory cannot be trusted (Babbie,2004:305). Taking foot notes assisted in transcribing and was the first step of data analysis.

\section{Trustworthiness}

Qualitative researchers use different criteria of trustworthiness when defining reliability and validity. They use terms 
such as consistency, dependability, conformability, credibility and transferability (Leiniger 1991 in Brink 1996:124).

Trustworthiness was maintained by using strategies of credibility, transferability, dependability and conformability (Lincoln \& Guba, 1985:290-327). Credibility was achieved by cross-examination of data which was done by reading the transcripts in their entirety several time, immersing in the details getting the sense of the interviews before categorizing the data (De Vos, Strydom, Fouche, \& Delport 2003, 343) and, re-coding the existing data where necessary. Dependability was ensured by dense description of data and the use of the co-coder. Transferability was ensured by selecting the sample and a context from which much can be learned about facilitation which is a phenomenon of interest hence purposive sampling was used. Being close to respondents when conducting focus group interviews ensured conformability. Focus groups should be seen as a way of closing the gaps between people as interactions fosters understanding of each other from people sharing personal and similar experiences (de Vos, et al 2003, 307).Small groups of between 5-10 members as in focus groups interviews (Polit et al, 2001:265) are conducive to less physical distance and fosters closeness.

\section{Data Analysis and Discussions}

Data was analyzed by means of a combination of Tesch (1990) in Cresswell
(1994:153-155) who described eight steps of analyzing data and the basic steps of Giorgi (1970) as quoted by Omery (1983:49-63). Data was categorized according to repeated tendencies. After completing to analyze the data, the final copy of the product was submitted to the to co-coder for critique and/or acceptance.

\section{Description of the facilitation process (Figure1.1)}

Facilitators described the facilitation process in different ways as shown in Figure 1.1.

Facilitators described facilitation (see figure 1.1) as a challenge to them as expressed in the following quotation "I think facilitation is a challenge but I mean challenging in another way and in another sense. In the old traditional method you had this comfort zone around you. You were not required to be involved to the extent that you are involved now. You have to be more wideawake definitely". According to this quotation the focus of the challenge is the changing roles and the difference between facilitation and traditional lecture methods. The reason for this challenge is that lectures in contrast to facilitations consist of didactic exercises and the lectures have a lecture-based experience and it is understandable that they can feel uncomfortable with the role of facilitation (Dolmas et al, 2004:173).

Facilitators also mentioned that facilitation demands that they change their way of thinking and behaving in order to facilitate. In support to what is stated by facilitators, Johnston and Tinning (2001:101) says that facilitation demands a shift from a teacher to a student-centred instruction. Facilitation was also described by facilitators as a different way of teaching. Brobanck and MacGill (1998:145) in support to the views of the facilitators, describe facilitation as just another way of teaching.

All four groups of facilitators mentioned that it was difficult for them to facilitate in the beginning because as teachers they wanted to teach and talk. As one facilitator said, "I can say if you are a real lecturer in the traditional sense then it is difficult to back off".

Another source of difficulty as indicated by facilitators was the lack of structure on how to facilitate. The facilitators felt as though they did not have these guidelines which traditional teaching offers. Other researchers had the same perception of facilitation process in their studies. Fichardt and du Rand (2000:310), Biley and Smith (1999:1205-1212) in their studies, state that facilitators pointed out that there was insufficient structure provided and that they were worried whether the students obtained adequate information. The literature also documents that it is difficult to give meaningful 'hands on ' facilitation (HaithCooper, 2003: 598). However, all facilitators stated that they grasped the process of facilitation in the course of

\section{FIGURE 1.1: Description of facilitation}

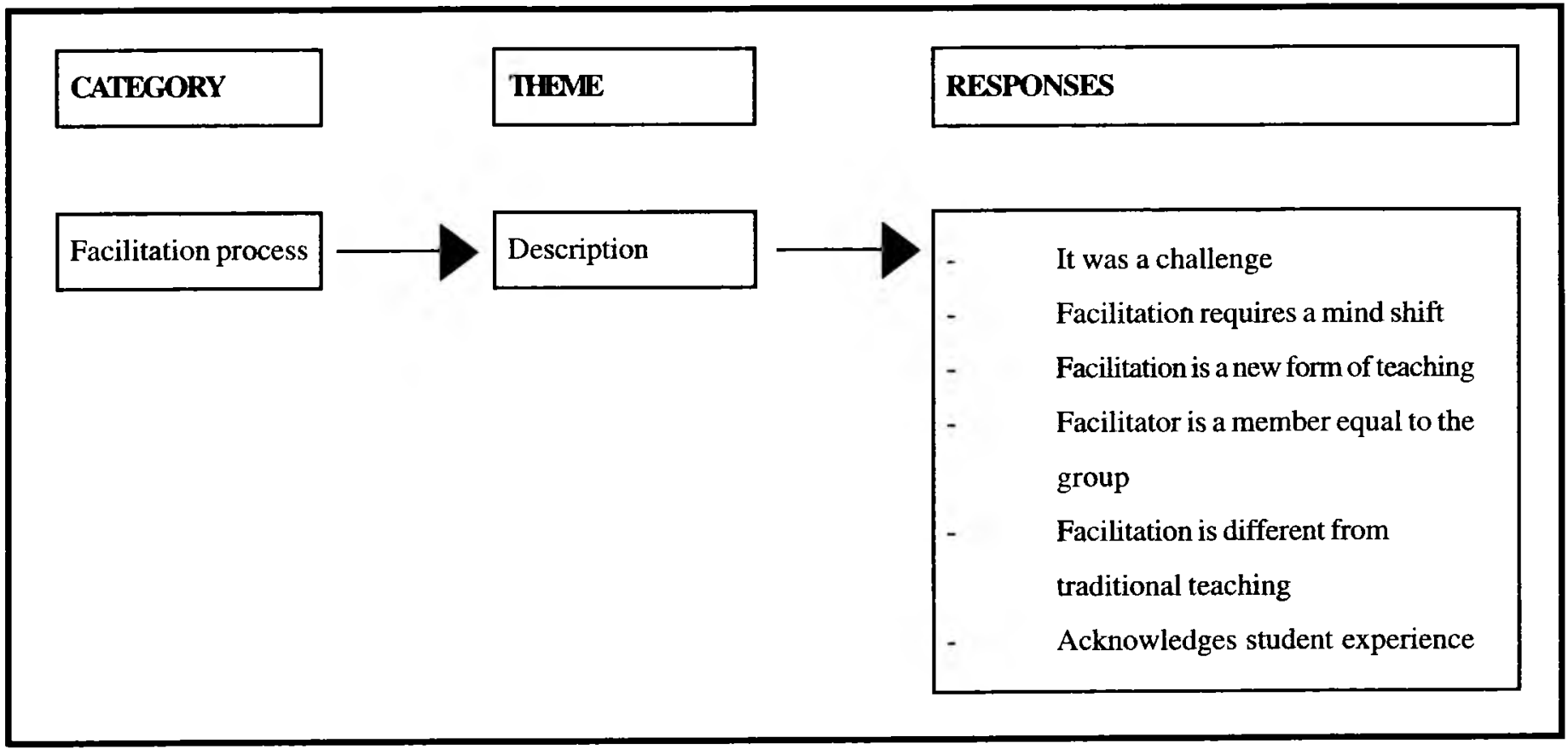




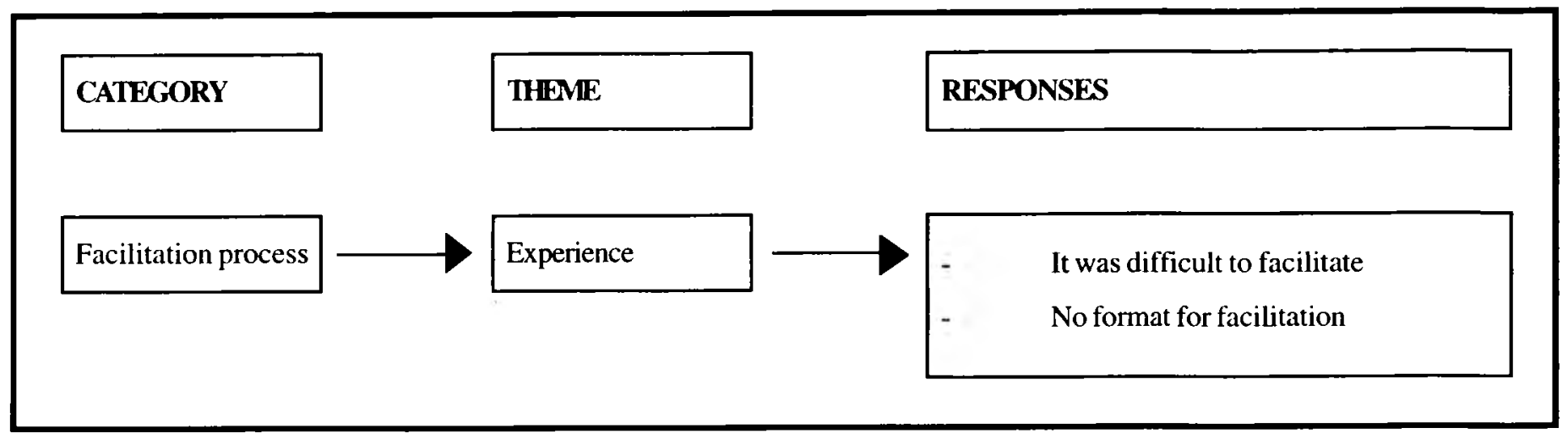

FIGURE 1.3: Emotions of facilitators

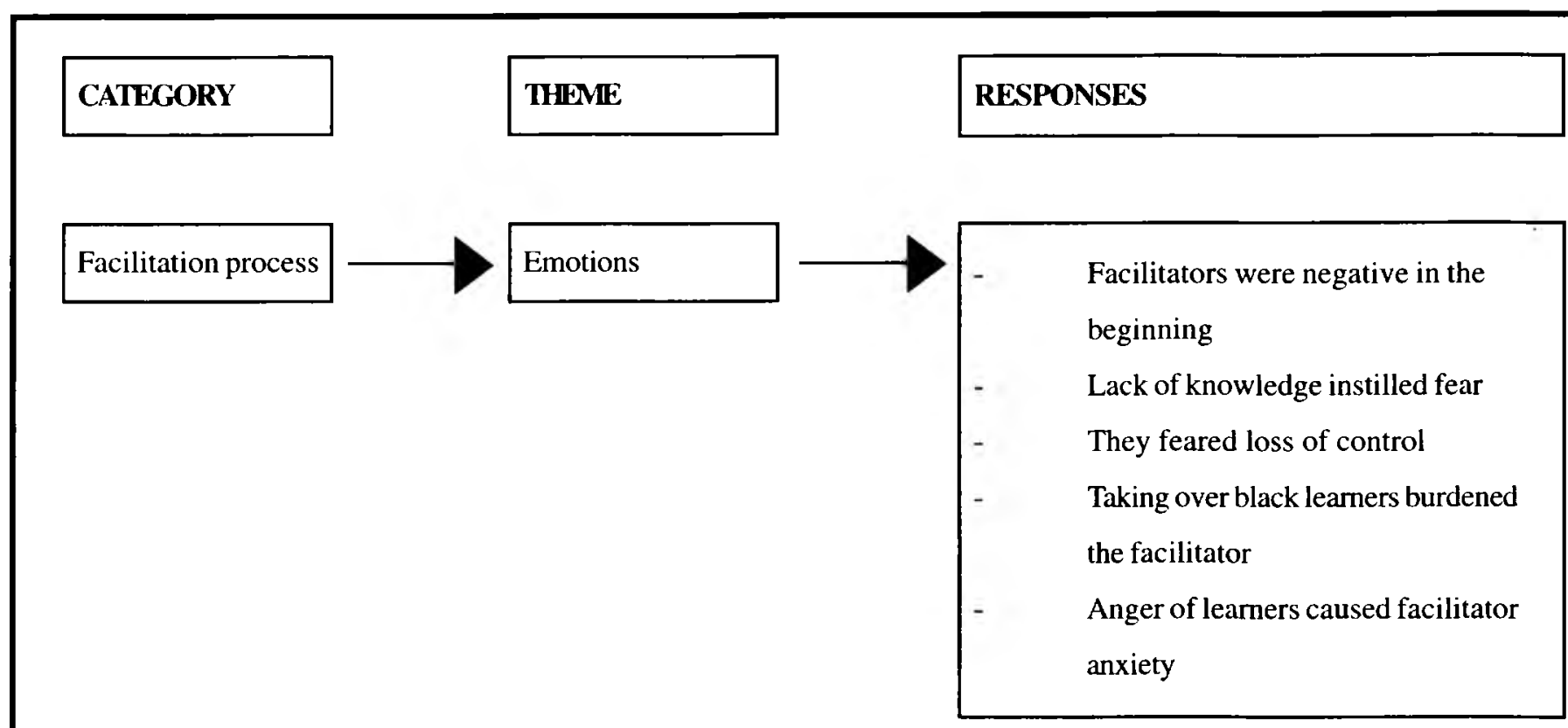

time. The increase in experience contributed to facilitators becoming comfortable with facilitation process ( $\mathrm{Mc}$ Lean, 2003:9). An example was voiced by a facilitator: "In the beginning it was difficult but after four to six months it became better to be a facilitator, for me it is now better to facilitate a group than to lecture. It has become very easy to facilitate".

Facilitators viewed themselves as members of the group who are equal to the group. The equality is all about sharing power and responsibility for learning. Brobanck and MacGill (1998) state that in this power-sharing relationship the facilitator remains an authority in terms of academic discipline. Facilitators explained that in facilitation the students have control over their learning as opposed to the traditional approach where the educator has all the control. Shovein, Huston, Fox and Damazo (2005: 341 ) insist that the educator must relinquish control and engage in a dialogue and consultation with students to promote independence. Musinski (1999:23-30) further emphasizes that traditional teaching approaches do not nurture the development of abilities to become an independent learner. Finally in describing facilitation, facilitators indicated that the students bring their experiences to the classroom. It is documented in the literature that adult learners bring experience-based insights and viewpoints about nursing and add thoughtful contributions to studentlearning activities (Shovein et al 2005:342).

\section{Emotions experience by the facilitators (Figure 1.3)}

It was evident that the process of facilitation imparted certain emotions amongst facilitators as indicated in figure 1.3. Literature also supports that change in teaching can lead to uncomfortable feelings ( Dolmas et al 2002:174.)
Because of the difficulty of facilitation, facilitators developed negative emotions such as fear of loss of control and the lack of knowledge of the facilitation process and other factors related to the process as indicated in figure 1.2. Katz (1995:54-55) explains that facilitators who experience difficulty in facilitating do so because of lack of experience and understanding of what facilitation involves. An additional burden was mentioned by one facilitator who facilitated black learners who were struggling with the content of learning possibly due to their educational background. She stated: "It was particularly hard for me as a black woman sitting and understanding the pain of those students going through emotions of not being able to say what you want to say, feelings of being inadequate. They were also frustrated and the pace of learning and the volume of theory was hard coming from rote learning and still struggling with the 


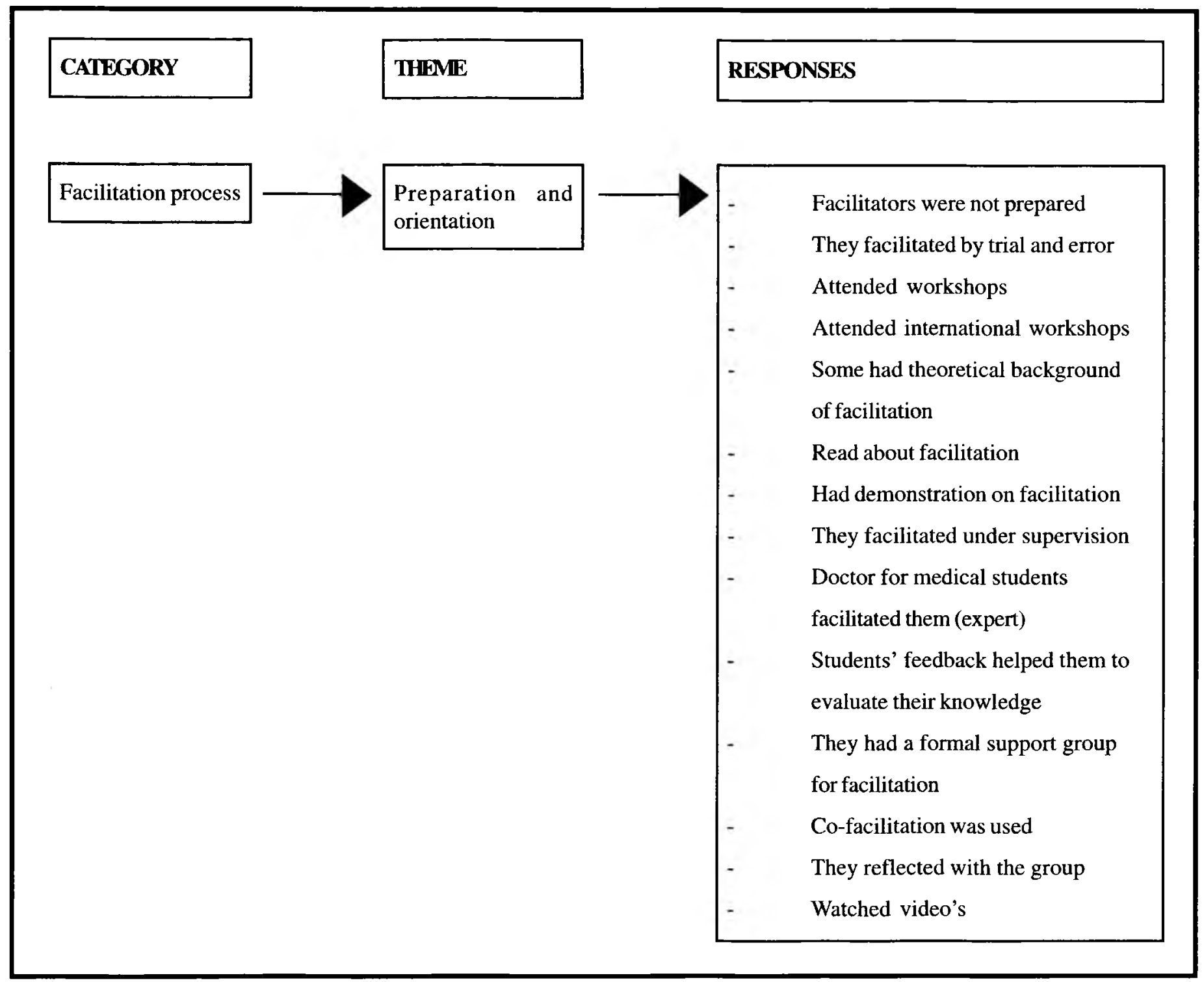

second language".Several studies conducted on the education of black students showed that African students lack the type of experience they need to be successful in a Western curriculum Holtzhausen (1999:2). The medium of instruction (English) also compounds the problem. Foley (2004: 63) state that many students are not sufficiently fluent in English which is the language of teaching and learning to succeed in higher education institutions. Hay \& Hay (2003:4) highlight that students coming from a non-English background require longer reading time to reach understanding. Brand (2003:29) mentions that there is no single answer in addressing challenges that students face when studying at tertiary level and emphasizes that the language policy and practices of each institution should be taken into consideration. Some facilitators mentioned that learners were angry about being facilitated and this caused anxiety on the part of facilitators. Several factors could have contributed to their anger. Students may for instance often feel frustrated when spending time reviewing material especially when they are unsure on how to learn and often felt as if they are not receiving guidance which is common in PBL facilitation ( Treloar, Mc Call, Rolfe, Pearson, Garvey Heathcote, 2000:710).

\section{Preparation for facilitation: Figure 1.4}

Different strategies were implemented to prepare facilitators for their new role as indicated in figure 1.4.

Some facilitators as reflected in figure 1.4 indicated that they had no formal preparation of facilitation and others stated that they had to facilitate by trial an error. Most facilitators stated that workshops were conducted and these are commonly used in attempt to prepare them for their new role (Maudsley, 2003:418).Other methods of preparation include an educational course with facilitation as a theoretical background, reading about facilitation, demonstrations, facilitation under supervision. The use of expert facilitators, making use of students' feedback as a means of improving their facilitation strategy. Studies has proven that students' feedback can be of assistance in assisting educators to change their methods of teaching (Pinto, Rendas and Gamboa (2001:292). Facilitators also depended on support groups from other facilitators who had knowledge of facilitation. In addition to support, group co-facilitation which is a strategy whereby colleagues sit in and take part in tutorials and comment on facilitation was used.This gives facilitators an opportunity to facilitate their peers and provides a safe environment for facilitators. In this process of co-facilitation facilitators work together, and model with each other within a teaching session. Johnston and 


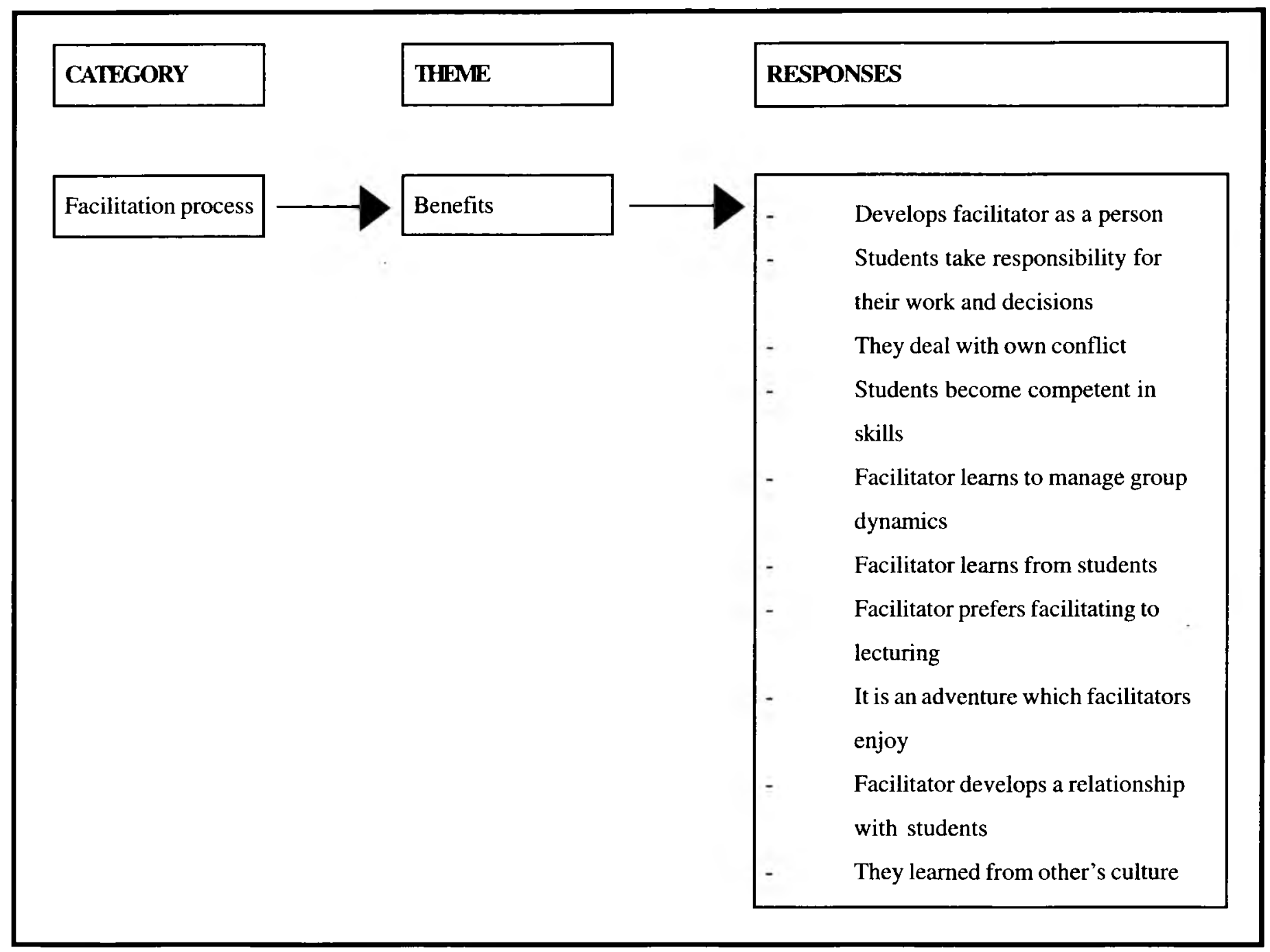

Tinning (2001:1) postulates that one factor that is that the use of group reflection is important in developing facilitators. Some facilitators watched videos to orientate themselves to facilitation process.

Literature indicates that one factor which has been found to be vital to the success of PBL methodologies is the effectiveness of the facilitator ( Johnston and Tinnings, 2001: 161). Good facilitation skills are considered to be important characteristics of an effective tutor (Trevena, 2003:55).The ability to promote group interaction, problem solving and the knowledge of when to intervene in the facilitation process forms part of effectiveness of the facilitator ( Haith-Cooper, 2003:65, Steinert, 2004:286, Johnston and Tinnings, 2001: 161). It was therefore important that facilitators are prepared and developed to facilitate learning.

\section{Challenges of the facilitation process (Figure 1.6)}

Challenges for this study are those factors in facilitation viewed as having a negative impact on facilitators. These will be discussed as indicated in Figure 1.6.

Facilitators were uncertain of whether the students would be able to cover the content and complete their learning outcomes. Steinert and Snell (1999:37-42) indicate that the fear of not covering content is a common phenomenon in interactive lectures and this is because facilitators think that they will sacrifice important content when students are more involved. Time constraints was mentioned as a challenge by facilitators. Some facilitators indicated that preparation for class was a challenge as it was time-consuming and that they needed to come to class well prepared. The following excerpt exemplifies such a concern "The difficulty we found was when do we fit the time frame because it took a long time. It took the whole morning to go through that problem and to come with the learning goals at the end of that session". The time factor is not related to facilitation per se but to the PBL approach which according to
Lehtinen (2002:109) because of its structure, is organized according to a sequence of distinguishable steps which consumes a lot of time to complete. Lack of structure was another concern highlighted by facilitators. some researchers also lamented that that facilitators as well as students perceived facilitated learning programmes lacked some structure and learning guidance ( Williams, MacDermid and Wessel 2003:206, Treloar et al, 2000:708).

\section{Benefits of facilitation (figure 1.5)}

Facilitation also had rewarding challenges for facilitators and students as reflected in figure 1.5

Facilitators indicated that the process of facilitation developed them personally and professionally. Thomas (2004: 136) maintain that facilitation is a body of knowledge and skills which should empower people. Studies indicate that the rewards of facilitation are numerous because they evoke a radical change in students and teachers alike, both personally and professionally (Cassimjee 

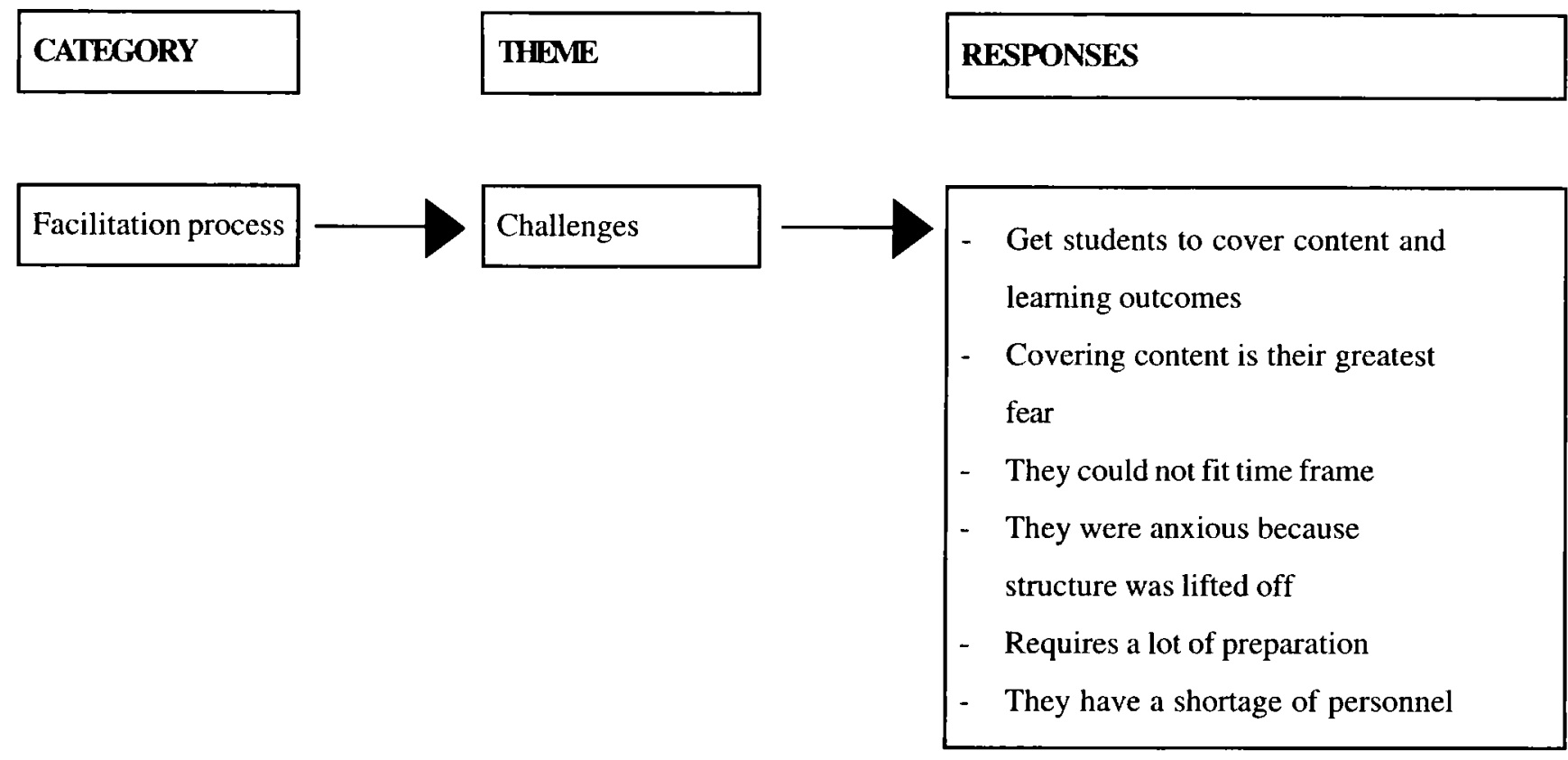

\& Brookes,1998:96). Facilitators also expressed that students were more responsible and they take decisions for their learning. An example of this responsibility is noted in the study conducted by Williams et al (2003:200) where facilitated students come with strategies to structure their learning, prepare for resource sessions and organize their notes. Students are said to be able to resolve conflict. Taylor (1997:67) states that students learn a great deal in groups about how to make decisions and handle conflict.

Another benefit identified is that students are more competent in their skills. Katz (1995:70) describes them as confident nurses both in the classroom and the clinical setting who question, challenge and refuse to be intimidated or silenced. Facilitators also mentioned that they gained group management skills and that they learned from students. Crew (1999:19-20) states that facilitators should look for knowledge useful to them from learners contribution and must act on the belief that they can learn from learners. Facilitators also indicated that they enjoyed facilitation. Other researches has also cited instances where facilitators enjoyed facilitation (Solomon \& Crowe, 2001:185). The following statements bear testimony to this statement:

"I feel facilitation is more enjoyable than the lecture method because when you facilitate you are moving together with the students".
"There is lots more to learn on how' to manage this. I wouldn't go back for anything, because of the richness of teaching and learning".

Facilitators also mention that they had a special relationship of caring and trust with their students. Finally some facilitators indicated that they learned about different cultures from their students. Junn (1994:130) asserts that each student brings into the classroom a wealth of unique or personal cultural knowledge that can be tapped as a rich learning resource.

\section{Conclusion}

The study was undertaken to determine the challenges that facilitators experienced in a problem-based setting within the context of nursing education. The data indicates that facilitation is a challenge for facilitators and it requires a total mind set change. Facilitators experience negative emotions in the beginning and fear loss of control. Adequate preparation for the role of facilitator and orientation seem to be very important to them. The research showed that although facilitators experienced difficulty in facilitating, some described it as a challenge with added advantages. Strategies that may assist in the preparation of facilitators in their role were recommended.

\section{Recommendations}

The recommendations for preparation of facilitators include orientation, education and support.

\section{Orientation}

All facilitators should be provided with orientation sessions. The orientation of facilitators should be designed with strategies that mirror the processes that students will undergo. In other words orientation sessions should be presented to resemble a typical learning package like the one students experience

\section{EDUCATION}

- $\quad$ Facilitators should be provided with a formal training programme before acting as facilitators.

- $\quad$ The training programme must include aspects that will develop specific facilitation skills such as communication, knowledge of group dynamics, questioning, probing, conflict management, negotiation, and guiding of students.

- Different strategies should be used to train facilitators.

Examples of such strategies include exposure to supervised facilitation by an expert and visits to schools that have already adopted facilitation as a learning method.

- $\quad$ Programs for further development should be available in nursing schools. 
These may include in-service training for those already in the programme and mentoring for novice facilitators.

- Guidelines for facilitation should include development of abilities to do the following:

- $\quad$ Structuring the leaming process

- Guiding learners

- Identifying learning resources

- Creating a conducive learning environment

- Encouraging cultural competency

- Motivating and supporting learners

- Being a role model

- Sometimes acting in a parental role

\section{Support for facilitators}

- $\quad$ Co-facilitation can be used as a strategy to prepare facilitators. In this process facilitators work with each other within a teaching session.

- $\quad$ Novice facilitators should have an induction program designed to ensuring effective performance in the initial period until they have mastered the process of facilitation.

- $\quad$ Experienced facilitators should be used as mentors to support the novice during the induction period.

\section{References}

BABBIE, E 2004: The practice of social research. 10 $0^{\text {th }} \mathrm{Ed}$. Thomson-Wadsworth. Australia

BECKER, S 1999: Evaluation of problem-based learning in an undergraduate nursing education programme. Bloemfontein: University of the Free State (M.Soc.Sc. in Nursing).

BLEY,FC \& SMITH, KL 1999: Making sense of problem-based learning: The perceptions and experiences of undergraduate nursing students. Journal of Advanced Nursing. 30(5): 1205-1212.

BITZER, EM \& PRETORIUS, EvE 19\%:

Resource-based learning at the UOFS: Background, meaning, implications and possible solutions. Bloemfontein: University of the Free State (unpublished manuscript).

BRAND, G 2003: Imagining a multilingual academy: rethinking language in higher education. SAJHE. 17 (3): 26-35.

BRINK, HI 1996: Fundamentals of research methodology for health care professionals. Cape Town: Juta \& Co. Ltd.

BROCKBANK, A \& McGILL, I 1998: Facilitating reflective leaming in higher education. Philadelphia: Open University Press.

CASSIMJEE, $R$ \& BROOKES, HB 1998: The concerns and/or fears of undergraduate students in a problembased community-based curriculum. South African Journal of Higher Education. 12(1):95-102.

CIIAKALANE-MPELI,RM 2005: Needs of children affected by HIV/AIDS; Mangaung in the Free State. Bloemfontein: University of the Free State (M.Soc.Sc. in Nursing).

CRESWELL, JW 1994: Research design. Qualitative and quantitative approaches. London: Sage Publication.

CREW, ED 1995: Trading places. Tutors and learners as partners. Adult Learning. 6(3):19-20.

De VOS, AS; STRYDOM, CB; FOUCHE, CB \& DELPORT, CSL 2003: Research at grass roots for Social Sciences Profession. $2^{\text {nd }}$ Edition. Van Schaik. Pretoria.

DOLMAS, DHJ; GIJSELAERS, WH; MOUST, JHC; DE GRAVE, WS; WOLFHAGEN, IHA \& VAN DER VLEUTEN, CPM 2002: Trends in research on the tutor in problem-based learning: conclusions and implications for educational practice and research. Medical Teacher. 24(2) 173-180.

FICHARDT, AE \& DU RAND, PP 2000: Facilitator's perceptions of problembased learning and community-based education. Health SA Gesondheid. 5(2):310.

FOLEY, A 2004: Language policy for higher education in South Africa: implications and complications. SAJHE. 18(1): 57-71.

HAITH-COOPER, M 2003: An exploration of tutor's experience of facilitating problem-based learning. Part 2-Implications for the facilitation of problem-based learning. Nurse education today, 23 (1):65-75.

HAY, HR \& HAY, J 2003: Postgraduate supervision in a globalized higher education system : Challenges for developing countries. Journal for new Generation Science. Vol 1 (2): 1-9.

HOLTZHAUSEN, SW 1999: Change in higher education: The psychological experience of facilitators and coordinators in a resource-based learning course. Bloemfontein: University of the Free State (dissertation submitted in fulfilment of the requirements for Masters Societatis Scientiae).

JOHNSTON, AK \& TINNINGS, RS 2001: Meeting the challenges of problem-based learning: developing the facilitators. Nurse Education Todáy. 21 (3):161-169.

JUNN, EN 1994: Experiential approaches to enhancing. Cultural awareness. In: Halpern, D.F. (Ed.) Changing college classrooms. New teaching and learning strategies for an increasingly complex world. San Francisco: Jossey-Bass Publishers.

KATZ, G 1995: Facilitation. In: Alavi, C. (Ed.) Problem-based learning in a health services curriculum . London: Routledge.

KWAN, C 2004: Learning A Medical Pharmacology Via Innovation: A Personal Experience At McMaster And In Asia. Acta pharmacologica. 25 (9): 1186-1194.

LEHTINEN, E 2002: Developing models for distributed problem-based learning: Theoretical and methodological reflection. Distance Education. 23 (1) : 109117.

LINCOLN, Y \& GUBA, E 1985: Naturalistic enquiry. Califomia: sage.

MAUDSLEY, G 2003: The limits of tutor's comfort zones with four integrated knowledge themes in a problem-based undergraduate medical curriculum (Interview study). Medical Education Volume 33:417-423.

McLEAN, M 2003: What can we learn from facilitators and student perceptions of facilitation skills and roles in the firs year of a problem-based learning 
curriculum?.BMC Medical Education. 3 (9).

MOLOTO, JC 1999: A model for the reintegration of marginalized adolescents into the community to facilitate the restoration, promotion and maintenance of their mental health. Johannesburg: Rand Afrikaans University (doctoral degree).

MTSHALI, NG 2005: Conceptualisation of community-based nursing education in South Africa: A Grounded theory analysis. Curationis. (28) 2:5-12.

MUSINSKI, B 1999: The educator as facilitator. A new kind of leadership. Nursing Forum. 34(1):23-29.

OMERY, A 1983: Phenomenology: A method for nursing research. Advances in Nursing Science. 5(2):49-63.

\section{PINTO,PR; RENDAS, A \& GAMBOA,} $T$ 2001: Tutors' performance evaluation: A feedback tool for the PBL learning process. Medical Teacher. 23(3):289-293.

POLIT, DF; BECK, CT \& HUGLER, BP 2001: Essentials of Nursing Research: Methods Appraisals and utilisation. $5^{\text {th }}$ Ed. Philadelphia. Lippincot.

SHOULTZ, J; KOOKER, BM; SLOAT, AR \& HATCHER, PA 1998: Four ways to teach PHC in a changing world. International Nursing Review.45(6): 187 192.

SOLOMON, P \& CROWE, J 2001: Perceptions of student peer tutors in a problem-based learning programme. Medical Teacher, 23(2): 181-186.

STEINERT, Y \& SNELL, LS 1999: Interactive lecturing: Strategies for increasing participation in large presentations. Medical Teacher. 21(1):3742.

STEINERT, Y 2004: Student perceptions of effective small group teaching. Medical Education. 38 (3): 286-93.

STREUBERT SPEZIALE, HJ \& CARPENTER, DR 2003: Qualitative research in nursing. Advancing the humanistic imperative. $3^{\text {rd }}$ ed. Philadelphia. Lippincott: Williams \& Wilkins.
DAMAZO, B 2005: Challenging traditional teaching and Learning paradigms: Online learning and emancipatory teaching. Nursing Education Perspectives. 26 (6):340-343.

TAYLOR, I 1997: Developing learning in professional education - partnership for practice. The Society for Research into Higher Education and Open University Press.

THOMAS, G 2004: A typology of Approaches to facilitator Education. Journal of Experiential Education. 27 (2) : 123-140.

TRELOAR, C; MCCALL, N; ROLFE, I; PEARSON, S; GARVEY, G \& HEATHCOTE, A 2000: Factors affecting progress of Australian and international students in a problem-based learning medical course. Medical Education Volume 34: 708-715.

TREVENA, L 2003: What Medical Students Value In A Population Health Tutor: Characteristics For Consideration In Staff Recruitment And Development. Education for Health. 16(1): 51-58.

WILLIAMS, R; MACDERMID, J \& WESSEL, J 2003: Student adaptation to problem-based learning in an entrylevel master's physical therapy program. Volume 19: 199-212.

WILLIAMS,A \& WILLIAMS, PJ 1994: Problem-based learning: An approach to teaching technology. In: Ostwald, M.J. \& Kingsland, A.J. (Eds.) Resource and development in problem-based learning. Australia. 